\title{
Genetics of obesity
}

\author{
Stephen O'Rahilly and I. Sadaf Farooqi* \\ Departments of Medicine and Clinical Biochemistry, University of Cambridge, PO Box 232, \\ Addenbrooke's Hospital, Cambridge CB2 2QQ, UK
}

\begin{abstract}
Considerable attention is currently being paid to the secular changes in food intake and physical activity that underlie the increase in the prevalence of obesity that is apparent in many societies. While this is laudable it would be unwise to view these environmental factors in isolation from the biological factors that normally control body weight and composition and the compelling evidence that interindividual differences in susceptibility to obesity have strong genetic determinants. This is particularly important, as it is only in the past decade that we have begun to obtain substantive information regarding the molecular constituents of pathways controlling mammalian energy balance and therefore, for the first time, are in a position to achieve a better mechanistic understanding of this disease. Population-based association and linkage studies have highlighted a number of loci at which genetic variation is associated with obesity and related phenotypes and the identification and characterization of monogenic obesity syndromes has been particularly fruitful. While there is widespread acceptance that hereditary factors might predispose to human obesity, it is frequently assumed that such factors would influence metabolic rate or the selective partitioning of excess calories into fat. However, it is notable that, thus far, all monogenic defects causing human obesity actually disrupt hypothalamic pathways and have a profound effect on satiety and food intake. To conclude, the evidence we have to date suggests that the major impact of genes on human obesity is just as likely (or perhaps more likely) to directly impact on hunger, satiety and food intake rather than metabolic rate or nutrient partitioning. At the risk of oversimplification, it seems that from an aetiological/genetic standpoint, human obesity appears less a metabolic than a neuro-behavioural disease.
\end{abstract}

Keywords: obesity; genetics; leptin; syndromes

\section{INTRODUCTION}

The recent and relatively rapid rise in the prevalence of obesity in the last 30 years has led some to question the importance of genetics in the aetiology of obesity. It is clear that secular changes in obesity prevalence have arisen as a consequence of changes in our environment, often seen most dramatically in recently urbanized populations, such as Fiji where the prevalence of obesity has increased markedly in the last 30 years (Ulijaszek 2005). Further evidence for the critical role of environmental factors in the development of obesity comes from migrant studies where a marked change in body mass index (BMI) is frequently witnessed where subjects with a common genetic heritage live under new and different environmental circumstances. Pima Indians, for example, living in the United States are on average $25 \mathrm{~kg}$ heavier than Pima Indians living in Mexico (Kopelman 2000). A similar trend is seen for Africans living in the United States and Asians living in the United Kingdom (Jebb et al. 2004).

The increased availability of palatable, energy dense foods and the reduced requirement for physical exertion during working and domestic life contributes to a state of positive energy balance, which over a period of time is sufficient to lead to a shift in the mean BMI of a population. However, there has also been a

* Author for correspondence (isf20@cam.ac.uk). One contribution of 16 to a theme issue 'Appetite'. change in the pattern of obesity in the last 30 years with a positive skew in the BMI distribution which appears to be attributable to a greater number of people with severe obesity.

\section{HERITABILITY OF BODY WEIGHT}

The heritability of a trait is defined as the per cent of inter-individual variation in that trait that can be explained by inherited factors. When considering obesity, clearly heritability is not a fixed entity, as the proportion of the phenotype that can be explained by the genotype will be influenced by the varying exposure to obesogenic environmental factors in different individuals and families. The comparison of monozygotic and dizygotic twin pairs has traditionally been one of the most powerful ways of obtaining a reliable estimate of heritability. In the case of BMI there have been over 30 published studies (Maes et al. 1997), and the estimated heritability of BMI ranges between 64 and 84\% (Stunkard et al. 1986a).

Studies of pairs of monozygous twins reared apart, which remove the potential confounding factor of twins sharing very similar post-natal (if not pre-natal) environments, provide the most powerful test of heritability. Among 25000 pairs of twins born in Sweden between 1886 and 1958 (Stunkard et al. 1990), the intrapair correlation for monozygotic twins reared apart was the most direct estimate of heritability for BMI and was calculated as 0.70 for men and 0.66 
for women. Similarly, a heritability of 0.61 was observed in a cohort of UK twins (Price \& Gottesman 1991). In a meta-analysis of results derived from Finnish, Japanese and American archival twins, Allison observed similar heritabilities (Allison et al. 1996). In addition, Price and colleagues have shown that estimates of heritability did not differ significantly between twins reared apart and twins reared together and between twins reared apart in relatively more similar (i.e. with relatives) versus less similar environments (Price \& Gottesman 1991).

Adoption studies provide a useful way of separating the common environmental effects since adoptive parents and their adoptive offspring share only environmental sources of variance, while the adoptees and their biological parents share only genetic sources of variance. One of the largest series, based on over 5000 subjects from the Danish adoption register which contains complete and detailed information on the biological parents, showed a strong and statistically significant relationship between the BMI of adoptees and biological parents across the whole range of body fatness, but none between adoptees and adoptive parents (Stunkard et al. 1986b). The Danish group have also shown a close correlation between BMI of adoptees and their biological full siblings who were reared separately by the biological parents of the adoptees and a similar, but weaker relationship with half-siblings (Sorensen et al. 1989).

It has long been considered that genetic variation between individuals is likely to influence responses to environmental factors such as diet and levels of physical activity. In a series of classical twin studies, Bouchard and colleagues tested the effects of heredity on weight gain and weight loss in response to positive and negative energy balance in 12 male monozygotic twin pairs (Bouchard \& Tremblay 1990). In a 100 day, continually supervised in-patient overfeeding study, subjects were given a $1000 \mathrm{kcal}$ per day surplus over the energy cost for weight maintenance (Bouchard et al. 1990). The amount of weight gained during this forced overfeeding varied from 3 to $12 \mathrm{~kg}$. There was at least three times more variance in response between twin pairs than within pairs for the gains in body weight, fat mass and fat-free mass. The most powerful predictor of the amount of weight gained was the amount gained by the subject's identical twin. This strongly suggests that when food intake and exercise are controlled, inherited factors influencing either energy expenditure or nutrient partitioning has an important influence on weight gain. Similar data was obtained by the same group when inducing negative energy balance in identical twin pairs (Bouchard et al. 1996).

Obesity may arise as a result of increased energy intake, decreased energy expenditure or increased partitioning of nutrients into fat, either alone or in combination. It would be useful if we could reliably measure the extent to which each of these processes might be under genetic control in humans. However, reliable data on food intake is difficult to obtain in the free-living situation, although where such measurements have been performed, twin data suggest that there are likely to be genetic influences on the intake of nutrients, size and frequency of meals and intake of particular foods (Wade et al. 1981). In contrast, energy expenditure can be more accurately assessed using a variety of techniques, including doubly labelled water. Bouchard \& Tremblay have shown that about $40 \%$ of the variance in resting metabolic rate, thermic effect of food and energy cost of low to moderate intensity exercise may be explained by inherited characteristics (Bouchard \& Tremblay 1990). In addition, significant familial resemblance for level of habitual physical activity has been reported in a large cohort of healthy female twins (Samaras et al. 1999).

\section{METHODOLOGICAL ISSUES IN GENETIC STUDIES}

Obesity is defined as an excess of body fat, which can be measured directly using dual energy X-ray absorptiometry and isotopic dilution techniques (Goodpaster 2002). However, these are costly and their limited availability makes it difficult to perform such measurements in large numbers of subjects. In some studies, fat mass has been measured indirectly using bioelectrical impedance or skin-fold thickness both of which correlate reasonably well within the normal range but less so in the very lean or the obese. The most commonly used marker of adiposity is BMI (weight in $\mathrm{kg} /$ height in $\mathrm{m}^{2}$ ) which is a measure of heaviness that can be performed in large epidemiological studies and correlates reasonably well with body fat content.

Body fat distribution provides an additional risk and abdominal fat mass can vary significantly within a narrow range of total body fat or BMI. Furthermore, within a given BMI, men have on average twice the amount of abdominal fat compared to pre-menopausal women. There are several methods to accurately localize body fat distribution in humans (computer tomography, ultrasound and magnetic resource imaging), but these methods are often impractical and expensive and difficult to perform in large numbers of subjects. The waist to hip ratio (WHR) has been used to identify subjects with abdominal fat accumulation (WHR of greater than 1.0 in men and greater than 0.85 in women) as has waist circumference alone, which is a convenient and simple measurement and correlates well with BMI, WHR and most importantly with risk factors for cardiovascular disease. A waist circumference of greater than $102 \mathrm{~cm}$ (approx. 40 inches) in men and greater than $88 \mathrm{~cm}$ (approx. $35 \mathrm{inch}$ ) in women is consistent with abdominal obesity and provides a substantial increased risk for metabolic complications (Aronne 2002). Surrogate markers of adipose tissue mass such as the adipocyte derived protein leptin (which correlates positively and closely with fat mass, $r=0.8$ ) have been used in some studies (Comuzzie 2002).

Some studies either focus on, or incorporate 'intermediate phenotypes' in their analyses. Such traits have the theoretical advantage that they may be more proximally related to the function of the gene under study. Thus a gene, which influenced energy expenditure might be easier to identify if one studied resting metabolic rate as the outcome variable. Intermediate phenotypes frequently used include resting metabolic rate, respiratory quotient $(\mathrm{RQ})$, insulin sensitivity and food intake and preferences measured using questionnaire based methods. 


\section{OBESITY AS A DISEASE STATE OR ADIPOSITY AS A CONTINUOUS VARIABLE}

Obesity as a clinical condition is currently defined as an excess accumulation of adipose tissue resulting in a BMI greater than $30 \mathrm{~kg} \mathrm{~m}^{-2}$. While the diagnosis of obesity by this criterion has clinical relevance with regards to intervention, management and treatment and from an epidemiological perspective, it may hamper the study of the genetics underlying variation in body fat mass and distribution. For example, BMI exhibits a normal distribution with no clear division between the 'clinically obese' (BMI $>30)$ and the nonobese. Such a pattern of continuous distribution is not restricted to merely BMI but is found in all obesityrelated phenotypes, including anthropometric measures (e.g. skin folds, and waist circumference), measures of body composition (e.g. per cent body fat, fat mass) and associated biochemical markers (e.g. leptin). Therefore, the division of individuals into 'cases' versus 'controls' or 'obese' versus 'non-obese' categories has a certain degree of arbitrariness that does not appear to follow any underlying biological effect (that might be due to the effect of a gene/genes). A complex phenotype by definition is a quantifiable characteristic that is influenced by both multiple genetic and non-genetic factors as well as their interactions, leading to variation in expression across the population. Thus the use of a definition (which takes continuously distributed measures and converts them to such dichotomous states as obese versus non-obese) may actually hinder attempts to identify genes influencing complex phenotypes by greatly decreasing statistical power. Significant information may be lost in the transition from a continuous to a discontinuous scale and these issues need to be considered when selecting the appropriate method for genetic analyses of these traits (Comuzzie et al. 2001).

\section{PROGRESS IN THE IDENTIFICATION OF HUMAN OBESITY GENES}

\section{(a) Linkage studies in common obesity}

The number of genome wide scans conducted in human populations has risen steadily over the last few years. While many of these studies have yielded somewhat equivocal results, often due to limited sample size, there are now several studies showing significant evidence of linkage (log odds ratio (LOD) scores greater than 2.5) and these are discussed in this section. For a comprehensive list of all linkage studies performed see the human obesity gene map established by Bouchard, Chagnon, Perusse and colleagues at The Pennington Biomedical Research Centre (http://www. obesite.chaire.ulaval.ca/genemap.html).

To date, significant linkage results for obesity related phenotypes have been published from a wide variety of human populations, and importantly several studies have now replicated human obesity quantitative trait loci across different ethnic groups (summarized in table 1). To this extent, there is now an emerging pattern with evidence that several major genes contribute to the variation in obesity related phenotypes in humans. Interestingly, not only are these linkage signals supported by significant LOD scores but many of these areas contain strong positional candidate genes for obesity related phenotypes.

At present, the strongest evidence for a quantitative trait locus (QTL) influencing obesity-related phenotypes in humans comes from the San Antonio Family Heart Study (SAFHS) with a LOD score for serum leptin levels on chromosome 2 of 7.5 (Comuzzie et al. 1997). This study used a sample of 459 Mexican Americans distributed in 10 families. The chromosome 2 QTL localizes very near the POMC locus, which encodes proopiomelanocortin (POMC). Hixson and colleagues detected significant association $(P=0.001)$ between molecular variation in the POMC locus and variation in serum leptin levels among Mexican Americans (Hixson et al. 1999).

The Pima Indian community of Arizona, which has a particularly high prevalence of obesity, was among the first to be examined in a genome-wide scan. Currently, QTLs have been detected on chromosomes 1, 3, 6, 11, 18 and 20 with LOD scores ranging from 2 to 3.6. The strongest evidence for a QTL in the Pima is on chromosome 11 (approx. 11q21-q24) with a LOD score of 3.6 for BMI (Hanson et al. 1998). Additional obesity-related phenotypes, including per cent of body fat $(\mathrm{LOD}=2.8)$ and $24 \mathrm{~h}$ energy expenditure $(\mathrm{LOD}=2.0)$ have also yielded linkage signals in this region in the Pima. There is evidence for a QTL located on chromosome 20 (approx. 20q11.2) for $24 \mathrm{~h}$ respiratory quotient (RQ) with a LOD score of 3.0. Norman et al. detected a LOD score of 2.3 on chromosome 18 (18q21) for percent body fat and a LOD score of 2.8 for $24 \mathrm{~h}$ RQ on chromosome 1 (1p31-p21; Norman et al. 1998).

Several groups have now published the results from genome screens conducted in populations of Western European (Caucasian) ancestry. The largest of these studies has been based on a collection of nuclear families collected from the mid-western region of the United States with 2209 individuals from 507 families (Kissebah et al. 2000). Kissebah and colleagues detected a QTL on chromosome 3 (3q27) strongly linked to a number of traits related to obesity (including BMI, waist circumference and fasting insulin) with LOD scores ranging from 2.4 to 3.5 (Kissebah et al. 2000). In addition, a second QTL influencing serum leptin levels was detected on chromosome 17 with a LOD score of 5.0. The region identified by the QTL on chromosome 3 contains several very promising positional candidate genes (e.g. adiponectin, GLUT2, $P I 3 K)$, as does the region containing the chromosome 17 QTL (e.g. GLUT4 and PPAR $\alpha$ ).

Hager and colleagues have published the results of a genome scan for obesity as a discrete trait (defined as a BMI > 27) in affected French sib pairs (Hager et al. 1998). Significant evidence of linkage on chromosome 10 (10p) with a LOD score of 4.9 was found. The same locus showed suggestive linkage (LOD=2.7) for BMIadjusted leptin in an Old Order Amish population. The gene $G A D 2$ encoding the glutamic acid decarboxylase enzyme (GAD65) is a positional candidate gene for obesity on chromosome 10p11-12. In a recent French case-control study of 575 morbidly obese and 646 control subjects, a protective haplotype including the most frequent alleles of two single nucleotide 
Table 1. Loci replicated in genome wide scans in obesity.

\begin{tabular}{|c|c|c|c|c|c|}
\hline locus & population & design & trait & LOD score/ $p$-value & candidate genes \\
\hline \multirow[t]{4}{*}{$2 p$} & Mexican American & extended pedigrees & leptin, fat mass & 7.5 & POMC \\
\hline & French Caucasian & sib pairs & leptin & 2.7 & POMC \\
\hline & African American & nuclear families & leptin & $p=0.008$ & \\
\hline & US Caucasian & nuclear families & adiponectin & 2.7 & \\
\hline \multirow[t]{5}{*}{$3 q$} & Pima Indian & sib pairs & leptin & 2.0 & Glut2 \\
\hline & African American & nuclear families & $\mathrm{BMI}$ & 1.8 & PI3 kinase \\
\hline & French Caucasian & sib pairs & BMI & 3.9 & \\
\hline & US Caucasian & nuclear families & $\mathrm{BMI}$ & 3.3 & \\
\hline & Indo-Mauritian & nuclear families & $\mathrm{CHD}$ & 3.1 & \\
\hline \multirow[t]{2}{*}{$4 p$} & US Caucasian & extended pedigrees & $\mathrm{BMI}$ & 6.1 & PPARGC1 CCKAR \\
\hline & Mexican American & extended pedigrees & $\mathrm{BMI}$ & 4.5 & \\
\hline \multirow[t]{3}{*}{5 cen-q } & French Caucasian & sib pairs & leptin & 2.9 & CART \\
\hline & African American & nuclear families & $\mathrm{BMI}$ & 1.9 & \\
\hline & US Caucasian & nuclear families & adiponectin & 4.1 & \\
\hline $6 \mathrm{q}$ & French Caucasian & extended pedigrees & BMI & 4.0 & SIM1, MCHR 2 and PC-1 \\
\hline \multirow{2}{*}{$8 \mathrm{p}$} & Mexican American & extended pedigrees & leptin, BMI & 3.1 & beta3 \\
\hline & US Caucasian & nuclear families & $\mathrm{BMI}$ & 2.0 & \\
\hline \multirow[t]{7}{*}{$10 p$} & Pima Indian & sib pairs & $\%$ body fat & 2.8 & none \\
\hline & Pima Indian & sib pairs & BMI & 3.6 & none \\
\hline & French Caucasian & sib pairs & leptin & 4.9 & \\
\hline & US Caucasian & nuclear families & adiponectin & 1.9 & \\
\hline & German Caucasian & nuclear families & BMI & 2.3 & \\
\hline & US Caucasian & nuclear families & $\mathrm{BMI}$ & 1.9 & \\
\hline & African American & nuclear families & BMI & 2.2 & \\
\hline $12 \mathrm{q}$ & Canadian & extended pedigrees & $\begin{array}{l}\text { abdominal subcu- } \\
\text { taneous fat by } \\
\text { CT }\end{array}$ & 2.88 & HNF-1 \\
\hline \multirow[t]{3}{*}{$17 p$} & Mexican American & extended pedigrees & $\mathrm{BMI}$ & 3.2 & Glut4 \\
\hline & & & & & $\operatorname{PPAR} \alpha$ \\
\hline & US Caucasian & nuclear families & leptin & 5 & \\
\hline \multirow[t]{4}{*}{$20 q$} & US Caucasian & nuclear families & $\mathrm{BMI}$ & 3.2 & GNAS1 \\
\hline & US Caucasian & nuclear families & $\mathrm{BMI}$ & 3.0 & CEBP-B \\
\hline & Pima Indian & sib pairs & $24 \mathrm{~h} R Q$ & 3.0 & ASIP \\
\hline & French Caucasian & sib pairs & BMI & 1.7 & \\
\hline $\mathrm{Xq} 23$ & Finnish & extended pedigrees & $\mathrm{BMI}$ & 3.1 & SLC6A14 \\
\hline
\end{tabular}

polymorphisms (SNPs) and an at-risk SNP for morbid obesity were identified (Boutin et al. 2003).

In a genome scan of Finnish obese nuclear families, using an affected sib pair design, Ohman and colleagues identified a susceptibility locus on chromosome Xq24 (maximum-likelihood score 3.14; Ohman et al. 2000). By fine mapping, they reduced the linkage region to $4 \mathrm{Mb}$ and have identified three functional candidate genes, AGTR2, SLC6A14 and SLC25A5. Significant evidence for association was observed for a SNP in the SLC6A14 gene region and also with the SNP haplotypes of the same gene, and a significant difference in allele frequency between obese and nonobese individuals was observed in two independently ascertained Scandinavian cohorts (Suviolahti et al. 2003).

\section{(b) Association studies in common obesity}

To date, association studies have largely been restricted to candidate genes whose dysfunction might reasonably be expected to result in obesity by virtue of their having putative effects on energy intake, energy expenditure or nutrient partitioning. Genome-wide association studies are anticipated in the future. The interpretation of association studies always requires caution because of the possibilities of problems such as population stratification, small sample size and publication bias. Some of these problems are exemplified by a common polymorphism in the $\beta_{3}$-adrenergic receptor, where despite over 40 association studies, involving more than 7000 subjects, the findings have been markedly inconsistent (Barsh et al. 2000). While significant and consistent associations have been obtained in large case-control studies for some variants including the insulin VNTR (Le Stunff et al. 2001) and IGF-1 SNPs (t Hart et al. 2004), it is true to say that, as of now, no single common variant is widely accepted as unequivocally associated with an alteration in human adiposity. A possible exception is the V103I variant in the MC4R receptor, which has been studied in over 7000 individuals and appears to confer protection against obesity (Geller et al. 2004). However, the variant is quite rare (less than $1 \%$ ) and the confidence limits for the odds ratio are not far from unity. A comprehensive and updated reference for all association studies in obesity genetics is available in the form of the obesity gene map (http://www.obesite.chaire.ulaval.ca/gene map.html).

\section{GENE/ENVIRONMENT INTERACTION}

The ability to identify possible interactions between genes and environmental factors is difficult because 
Table 2. Human pleiotropic obesity syndromes.

\begin{tabular}{|c|c|c|c|}
\hline syndrome & additional clinical features & locus & gene \\
\hline \multicolumn{4}{|l|}{ autosomal dominant } \\
\hline Prader-Willi syndrome & $\begin{array}{l}\text { hypotonia, mental retardation, short stature, } \\
\text { hypogonadotropic hypogonadism }\end{array}$ & $\begin{array}{l}\text { lack of the paternal segment } \\
\qquad 15 \mathrm{q} 11.2-\mathrm{q} 12\end{array}$ & unknown \\
\hline Albright hereditary osteodystrophy & $\begin{array}{l}\text { short stature, skeletal defects, and impaired } \\
\text { olfaction }\end{array}$ & $20 \mathrm{q} 13.2$ & GNAS1 \\
\hline ulnar-mammary syndrome & $\begin{array}{l}\text { ulnar defects, delayed puberty, hypoplastic } \\
\text { nipples }\end{array}$ & $12 \mathrm{q} 24.1$ & TBX3 \\
\hline \multicolumn{4}{|l|}{ autosomal recessive } \\
\hline Bardet-Biedl syndrome & $\begin{array}{l}\text { mental retardation, dysphormic extremities, } \\
\text { retinal dystrophy or pigmentary retinopathy, } \\
\text { hypogonadism and structural abnormalities } \\
\text { of the kidney or functional renal impairment }\end{array}$ & $\begin{array}{l}\text { 1q13 (BBS1), 16q21 (BBS2), } \\
\text { 3p13 (BBS3), 15q22 } \\
\text { (BBS4), 2q31 (BBS5) } \\
\text { 20p12 (BBS6), 4q27 } \\
\text { (BBS7), 14q32 (BBS8) }\end{array}$ & \\
\hline Alstrom syndrome & $\begin{array}{l}\text { retinal dystrophy, neurosensory deafness, } \\
\text { diabetes }\end{array}$ & $2 \mathrm{p} 13$ & ALMS1 \\
\hline Cohen syndrome & $\begin{array}{l}\text { prominent central incisors, opthalmopathy, } \\
\text { microcephaly }\end{array}$ & $8 q 22$ & unknown \\
\hline \multicolumn{4}{|l|}{$X$-linked } \\
\hline fragile X syndrome & $\begin{array}{l}\text { mental retardation, hyperkinetic behaviour, } \\
\text { macroorchidism, large ears, prominent jaw, } \\
\text { and high-pitched jocular speech }\end{array}$ & $\mathrm{Xq} 27.3$ & FMR1 \\
\hline $\begin{array}{l}\text { Borjeson-Forssman-Lehmann } \\
\text { syndrome }\end{array}$ & mental retardation, hypogonadism, large ears & $\mathrm{Xq} 26$ & PHF6 \\
\hline Mehmo syndrome & $\begin{array}{l}\text { mental retardation, epilepsy, hypogonadism, } \\
\text { microcephaly }\end{array}$ & $\mathrm{Xp} 22.13$ & unknown \\
\hline Simpson-Golabi-Behmel-type 2 & $\begin{array}{l}\text { craniofacial defects, skeletal and visceral } \\
\text { abnormalities }\end{array}$ & $\mathrm{Xp} 22$ & unknown \\
\hline Wilson-Turner syndrome & $\begin{array}{l}\text { mental retardation, tapering fingers, } \\
\text { gynaecomastia }\end{array}$ & $\mathrm{Xp} 21.2$ & unknown \\
\hline
\end{tabular}

there may be a delay in an individual's exposure to an 'obesogenic' environment and uncertainty about the precise timing of the onset of weight gain. Polymorphisms in obesity candidate genes have been studied in a few population-based cohorts on whom extensive and detailed information on diet, physical activity and markers of intermediate metabolism have been measured. The relationship between the Pro12Ala variant in the nuclear receptor peroxisome proliferator-activated receptor- $\gamma$ (PPAR $\gamma$ ) and the ratio of dietary polyunsaturated fat to saturated fat ( $\mathrm{P}: \mathrm{S}$ ratio) has been studied and there is some evidence for a genenutrient interaction in a number of large studies (Lindi et al. 2002; Meirhaeghe et al. 2000a). Evidence for gene-exercise interactions have been found for variants in lipoprotein lipase in the HERITAGE Family Study and for the Gly16Arg variant in the $\beta_{2}$-adrenergic receptor in French and UK population-based cohorts (Meirhaeghe et al. 2000b; Meirhaeghe et al. 2001). These studies, although few in number, emphasize the difficulty of examining the effect of common polymorphisms in the absence of complete data on nongenetic exposures and may explain in part the heterogeneity of findings in previous studies.

\section{MONOGENIC DISORDERS LEADING TO HUMAN OBESITY}

It is well established that obesity runs in families, although the vast majority of cases do not segregate with a Mendelian pattern of inheritance. There are about 30 disorders with obesity as a clinical feature but often associated with mental retardation, dysmorphic features and organ-specific developmental abnormalities (i.e. pleiotropic syndromes). A number of families with these rare pleiotropic obesity syndromes have been studied by linkage analysis and the known chromosomal loci for obesity syndromes are summarized in table 2 . For a comprehensive list of syndromes in which obesity is a recognized part of the phenotype, see Online Mendelian Inheritance in Man (OMIM; http:// www.ncbi.nlm.nih.gov/omim/).

The study of a number of these syndromes has yielded novel insights into potential mechanisms implicated in the obesity in these patients in the last few years and we will restrict our discussion to these disorders. (For a more complete review of obesity syndromes see www.endotext.org).

\section{PRADER-WILLI SYNDROME}

The Prader-Willi syndrome (PWS) is an autosomal dominant disorder characterized by hypotonia, mental retardation, short stature, hypogonadotropic hypogonadism and hyperphagia and obesity. Sporadic deletion of the paternal chromosomal segment 15q11.2-q12 or loss of the entire paternal chromosome 15 with presence of two maternal homologues (uniparental maternal disomy) results in PWS (Amos-Landgraf et al. 1999). There is a lack of expression of paternally imprinted 
genes within the $4.5 \mathrm{Mb}$ PWS region and several candidate genes have been studied and their expression shown to be absent in the brains of PWS patients (Swaab et al. 1995). Recently, Wevrick and colleagues have showed that Necdin and Magel2 bind to and prevent proteasomal degradation of FEZ1, a protein implicated in axonal outgrowth and kinesin mediated transport and also bind to the Bardet-Biedl syndrome (BBS) protein BBS4 in vitro (Lee et al. 2005). Interactions among these molecules occur at or near centrosomes, and centrosomal dysfunction has been implicated in BBS and may be relevant to the common phenotypic features of learning disabilities, hypogonadism and obesity in these patients. However, the precise role of these genes and the mechanisms by which they lead to a pleiotropic obesity syndrome remain elusive.

There has been interest recently in the role of the enteric hormone ghrelin. Several groups have shown that children and adults with PWS have fasting plasma ghrelin levels that are 4.5 fold higher than equally obese controls. As ghrelin is implicated in the regulation of meal-time hunger in rodents and humans, these observations may implicate ghrelin in the pathogenesis of hyperphagia in these patients (Cummings et al. 2002; Haqq et al. 2003).

\section{BARDET-BIEDL SYNDROME}

BBS is a rare (prevalence less than 1/100 000), autosomal recessive disease characterized by obesity, mental retardation, dysphormic extremities (syndactyly, brachydactyly or polydactyly), retinal dystrophy or pigmentary retinopathy, hypogonadism and structural abnormalities of the kidney or functional renal impairment (Katsanis et al. 2001a,b). BBS is a genetically heterogeneous disorder that is now known to map to at least eight loci: $11 \mathrm{q} 13$ (BBS1; Mykytyn et al. 2002), 16q21 (BBS2; Nishimura et al. 2001), 3p13-p12 (BBS3; Sheffield et al. 1994), 15q22.3-q23 (BBS4; Mykytyn et al. 2001), 2q31 (BBS5; Young et al. 1999), 20p12 (BBS6; Slavotinek et al. 2000), 4q27 (BBS7; Badano et al. 2003) and 14q32.11 (BBS8; Ansley et al. 2003). Although BBS is usually transmitted as a recessive disorder, some families have exhibited so called 'tri-allelic' inheritance where the clinical manifestation of the syndrome requires two mutations in one BBS gene plus an additional mutation in a second, unlinked BBS gene (Katsanis et al. $2001 a, b)$.

The recent discovery of the novel BBS3, 5, 7 and 8 genes by phylogenetic/genomic approaches has led to progress in the understanding of the mechanisms underlying the pleiotropic features of BBS (Beales 2005). These proteins are all involved in basal body and centrosomal function and impact on ciliary development and transport (Mykytyn \& Sheffield 2004). BBS1, 2, 6 and 4 are all involved in intracellular trafficking (Nishimura et al. 2004) and mice lacking the Bbs4 protein recapitulate the major components of the human phenotype, including obesity and retinal degeneration (Mykytyn et al. 2004). It remains to be seen what role these proteins and organelles play in energy balance, cognitive impairment and renal development.

\section{TRKB DEFICIENCY}

Much evidence has emerged implicating the neurotrophin brain-derived neurotrophic factor (BDNF) and its receptor $\operatorname{TrkB}$ in the regulation of mammalian eating behaviour and energy balance (Huang \& Reichardt 2001; Kernie et al. 2000). Mice lacking either one copy of the $B d n f$ gene or with a tissue-specific conditional deletion of $B d n f$ in the post-natal brain (Rios et al. 2001) develop increased food intake (hyperphagia) and obesity. Similarly, mice with a hypomorphic mutation in trkb, resulting in 25\% normal levels of expression, also develop obesity (Xu et al. 2003).

We identified a single patient with a de novo mutation in the neurotrophin receptor TrkB which was associated with severe hyperphagia and obesity, delayed speech and language development, impaired short term memory and loss of nociception (Yeo et al. 2004).

\section{MONOGENIC OBESITY SYNDROMES WITHOUT DEVELOPMENTAL ANOMALIES OR MENTAL RETARDATION}

In the past 8 years several human disorders of energy balance that arise from genetic defects have been described. All of these are in molecules identical or similar to those known to cause obesity in genetic and experimental syndromes of obesity in rodents (Leibel et al. 1997) and all have been identified using a candidate gene approach. These mutations all result in morbid obesity in childhood without the developmental pleiotropic features characteristic of the recognized syndromes of childhood obesity (table 3 ).

\section{CONGENITAL LEPTIN DEFICIENCY}

The role of leptin was first discovered in studies of severely obese $o b / o b$ mice, which harbour mutations in the $o b$ gene resulting in a complete lack of its protein product leptin which is derived from adipose tissue (Zhang et al. 1994). Administration of recombinant leptin reduces the food intake and body weight of leptin-deficient $o b / o b$ mice and corrects all their neuroendocrine and metabolic abnormalities (Halaas et al. 1995).

In 1997, we reported two severely obese cousins from a highly consanguineous family of Pakistani origin who had undetectable levels of serum leptin and were found to be homozygous for a frameshift mutation in the $o b$ gene $(\Delta \mathrm{G} 133)$, which resulted in a truncated protein that was not secreted (Montague et al. 1997). We have since identified six further affected individuals from four other families who are also homozygous for the same mutation in the leptin gene. All the families are of Pakistani origin but not known to be related over five generations. A large Turkish family who carry a homozygous missense mutation have also been described (C105T; Strobel et al. 1998). All subjects in these families are characterized by severe early onset obesity and intense hyperphagia. Some of the Turkish subjects who are adults failed to undergo pubertal development with biochemical evidence of hypogonadotropic hypogonadism (Ozata et al. 1999). 
Table 3. Features of pure obesity syndromes.

\begin{tabular}{|c|c|c|c|c|c|c|}
\hline & appetite & energy expenditure & \multicolumn{2}{|c|}{ body composition } & \multicolumn{2}{|c|}{ insulin secretion } \\
\hline $\begin{array}{l}\text { leptin } \\
\text { leptin receptor } \\
\text { POMC } \\
\text { MC4R }\end{array}$ & $\begin{array}{l}\text { increased } \\
\text { increased } \\
\text { increased } \\
\text { increased }\end{array}$ & $\begin{array}{l}\text { BMR normal } \\
\text { BMR normal } \\
\text { BMR normal } \\
\text { BMR normal }\end{array}$ & \multicolumn{2}{|c|}{$\begin{array}{l}\text { selective fat deposition } \\
\text { selective fat deposition } \\
\text { unknown } \\
\text { excess fat and lean mass }\end{array}$} & \multicolumn{2}{|c|}{$\begin{array}{l}\text { mild, consistent with obesity } \\
\text { mild, consistent with obesity } \\
\text { unknown } \\
\text { severe, early hyperinsulinaemia }\end{array}$} \\
\hline & growth & puberty & & thyroid & & adrenal axis \\
\hline $\begin{array}{l}\text { leptin } \\
\text { leptin receptor } \\
\text { POMC } \\
\text { MC4R }\end{array}$ & $\begin{array}{l}\text { normal } \\
\text { reduced } \\
\text { increased } \\
\text { increased }\end{array}$ & \multicolumn{2}{|c|}{$\begin{array}{l}\text { hypogonadotropic hypogonadism } \\
\text { hypogonadotropic hypogonadism } \\
\text { normal } \\
\text { normal }\end{array}$} & \multicolumn{2}{|c|}{$\begin{array}{l}\text { central hypothyroidism } \\
\text { central hypothyroidism } \\
\text { ? hypothyroidism } \\
\text { normal }\end{array}$} & $\begin{array}{l}\text { normal } \\
\text { normal } \\
\text { ACTH deficiency } \\
\text { normal }\end{array}$ \\
\hline
\end{tabular}

We demonstrated that children with leptin deficiency had profound abnormalities of $\mathrm{T}$ cell number and function (Farooqi et al. 2002), consistent with high rates of childhood infection and a high reported rate of childhood mortality from infection in obese Turkish subjects. In leptin deficient humans, we found no detectable changes in resting or free-living energy expenditure, although it was not possible to examine how such systems adapted to stressors such as cold. Ozata et al. (1999) reported abnormalities of sympathetic nerve function in leptin deficient humans consistent with defects in the efferent sympathetic limb of thermogenesis. This contrasts with the more obvious impairment in energy expenditure seen in the $o b / o b$ mouse and may be explained by the sensitivity of available techniques for measuring energy expenditure in humans, the inability to see effects in the basal rather than stimulated states or may indeed reflect a true species difference.

\section{RESPONSE TO LEPTIN THERAPY}

We have reported the dramatic and beneficial effects of daily subcutaneous injections of leptin reducing body weight and fat mass in three congenitally leptin deficient children (Farooqi et al. 2002; figure 1). The major effect of leptin was on appetite with normalization of hyperphagia. Leptin therapy reduced energy intake during an $18 \mathrm{MJ}$ ad libitum test meal by up to $84 \%$ (Farooqi et al. 2002). We were unable to demonstrate a major effect of leptin on basal metabolic rate (BMR) or free-living energy expenditure, but, as weight loss by other means is associated with a decrease in BMR, the fact that energy expenditure did not fall in our leptin deficient subjects is notable. The administration of leptin permitted progression of appropriately timed pubertal development in the single child of appropriate age and did not cause the early onset of puberty in the younger children (Farooqi et al. 2002). Leptin also reversed the $\mathrm{T}$ cell dysfunction and caused a switch from a predominantly TH2 to a TH1 immune phenotype (Farooqi et al. 2002).

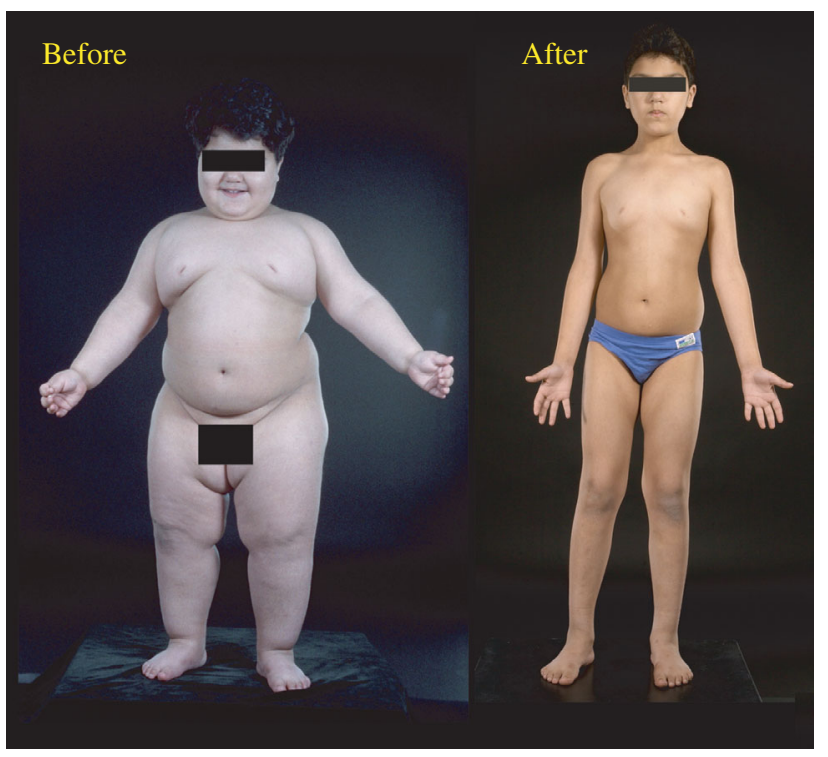

Figure 1. Response to leptin treatment in leptin deficiency.

\section{PARTIAL LEPTIN DEFICIENCY IN HETEROZYGOTES}

Leptin clearly has physiologically relevant effects at the lowest end of the dose response curve but can it regulate fat mass across the range seen in most overweight and obese people? One approach to addressing this question was to identify subjects with a relative deficiency of leptin. We studied the heterozygous relatives of our leptin deficient subjects (Farooqi et al. 2001). Serum leptin levels in the heterozygous subjects were found to be significantly lower than expected for per cent of body fat and they had a higher prevalence of obesity than seen in a control population of similar age, sex and ethnicity (Farooqi et al. 2001). Additionally, per cent of body fat was higher than predicted from their height and weight in the heterozygous subjects compared to control subjects of the same ethnicity. These findings closely parallel those in heterozygous $o b$ - and $d b /$ - mice (Chung et al. 1998). These data provide further support for the possibility that leptin can produce a graded response in terms of body composition across a broad range of plasma concentrations. 


\section{LEPTIN RECEPTOR DEFICIENCY}

The signalling form of the leptin receptor is deleted in $d b / d b$ mice (and disrupted in the fatty Zucker and Koletsky rat models) which are consequently unresponsive to endogenous or exogenous leptin (Tartaglia 1997). In rodents, the phenotype is comparable to $o b / o b$, with earlier development of hyperglycaemia on some backgrounds.

A mutation in the leptin receptor has been reported in three obese subjects from a consanguineous family of Kabilian origin (Clement et al. 1998). Affected individuals were homozygous for a mutation that truncates the receptor before the transmembrane domain and the mutated receptor circulates bound to leptin. Although this mutation does not result in a complete null phenotype, there are a number of phenotypic similarities with the leptin-deficient subjects (table 3). Leptin receptor deficient subjects were also born of normal birth weight, exhibited rapid weight gain in the first few months of life, with severe hyperphagia and aggressive behaviour when denied food.

\section{POMC DEFICIENCY}

The first-order neuronal targets of leptin action in the brain are anorectic (reducing food intake) POMC and orexigenic (increasing food intake) neuropeptideY/agouti-related protein (NPY/AgRP) neurons in the hypothalamic arcuate nucleus, where the signalling isoform of the leptin receptor is highly expressed (Schwartz et al. 2000). Forty per cent of POMC neurons in the arcuate nucleus express the mRNA for the long form of the leptin receptor and POMC expression is regulated positively by leptin. POMC undergoes extensive and tissue-specific post-translational processing by proprotein convertases (PCs) to yield a range of biologically active peptides (Coll et al. 2004). The expression of PC2 within the hypothalamus leads to the production of $\alpha-, \beta-$, and $\gamma$-MSH (the melanocortins), but not adrenocorticotrophic hormone (ACTH) which is the predominant peptide produced by pituitary corticotrophs that express prohormone convertase 1 (PC1).

Two unrelated obese German children with homozygous or compound heterozygous mutations in POMC have been reported (Krude et al. 1998). These children were hyperphagic, developing early-onset obesity as a result of impaired melanocortin signalling in the hypothalamus. They presented in neonatal life with adrenal crisis due to ACTH deficiency (POMC is a precursor of ACTH in the pituitary) and had pale skin and red hair due to the lack of MSH function at melanocortin 1 receptors in the skin (Krude et al. 1998). A number of groups have identified a heterozygous missense mutation (Arg236Gly) in POMC that disrupts the dibasic amino acid processing site between $\beta$-MSH and $\beta$-endorphin, resulting in an aberrant $\beta-\mathrm{MSH} / \beta$-endorphin fusion peptide which binds to MC4R with an affinity identical to that of $\alpha$ - and $\beta$-MSH but has a markedly reduced ability to activate the receptor (Challis et al. 2002). Thus this cleavage site mutation in POMC may confer susceptibility to obesity through a novel molecular mechanism.
17. PROHORMONE CONVERTASE 1 DEFICIENCY

Further evidence for the role of the melanocortin system in the regulation of body weight in humans comes from the description of a 47-year-old woman with severe childhood obesity, abnormal glucose homeostasis, very low plasma insulin but elevated levels of proinsulin, hypogonadotropic hypogonadism and hypocortisolaemia associated with elevated levels of POMC (O'Rahilly et al. 1995). This subject was found to be a compound heterozygote for mutations in prohormone convertase 1 , which cleaves prohormones at pairs of basic amino acids, leaving C-terminal basic residues which are then excised by carboxypeptidase $\mathrm{E}$ (CPE; Jackson et al. 1997). We have also recently identified a child with severe, early-onset obesity that was a compound heterozygote for complete loss of function mutations in PC1 (Jackson et al. 2003). Although failure to cleave POMC is a likely mechanism for the obesity in these patients, PC1 cleaves a number of other neuropeptides in the hypothalamus, such as glucagon-like-peptide 1 , which may influence feeding behaviour. Intriguingly, this second patient suffered from severe small-intestinal absorptive dysfunction as well as the characteristic severe early-onset obesity, impaired prohormone processing and hypocortisolaemia. We hypothesized that the small intestinal dysfunction seen in this patient, and to a lesser extent in the first patient we described, may be the result of a failure of maturation of propeptides within the enteroendocrine cells and nerves that express PC1 throughout the gut. The finding of elevated levels of progastrin and proglucagon provided in vivo evidence that, indeed, prohormone processing in enteroendocrine cells was abnormal.

\section{MELANOCORTIN 4 RECEPTOR DEFICIENCY}

The melanocortins mediate their effects through a family of five related $\mathrm{G}$ protein-coupled receptors, two of which, MC3R and MC4R, are highly expressed within the central nervous system (Gantz \& Fong 2003).

Of the two centrally expressed melanocortin receptors, the MC4R is the one most closely linked to energy homeostasis. Targeted disruption of MC4R in rodents leads to increased food intake, obesity, severe early hyperinsulinaemia and increased linear growth; heterozygotes have an intermediate phenotype compared to homozygotes and wild-type mice (Huszar et al. 1997).

Heterozygous mutations in $M C 4 R$ have been reported to cause a dominantly inherited obesity syndrome in different ethnic groups. In a study of 500 severely obese probands, we found that approximately $5 \%$ harboured pathogenic mutations in the MC4R gene, making this the commonest monogenic cause of obesity thus far described in humans (Farooqi et al. 2003). Recent studies in the Danish population provide an important indication of the likely population prevalence of this disorder. Pedersen and colleagues showed that in Danish men recruited to the draft board, $2.5 \%$ of those with a BMI $>30$ had a pathogenic mutation in MC4R (Larsen et al. 2005), confirming that MC4R deficiency is the commonest obesity 
syndrome described to date and is one of the commonest monogenic diseases. The fact that obesity is expressed in heterozygotes and the lack of any apparent effect of the mutations on reproductive function are factors which probably contribute to the maintenance of a reasonably high disease frequency. More recently, a small number of homozygotes for $M C 4 R$ mutations have been described; however, the heterozygotes in these families do have an intermediate phenotype consistent with a co-dominant mode of inheritance (Farooqi et al. 2003).

Detailed phenotypic studies of patients with melanocortin 4 receptor mutations reveal that this syndrome is characterized by an increase in lean body mass and bone mineral density, increased linear growth throughout childhood, hyperphagia and severe hyperinsulinaemia (Farooqi et al. 2003). These features are similar to those seen in $M C 4 R$ knockout mice, suggesting the preservation of the relevant melanocortin pathways between rodents and humans. Of particular note is the finding that the severity of receptor dysfunction seen in in vitro assays can predict the amount of food ingested at a test meal by the subject harbouring that particular mutation (Farooqi et al. 2003).

We have studied in detail the signalling properties of many of these mutant receptors and this information should help to advance the understanding of structure/function relationships and potentially provide in vitro support for the use of MC4R agonists in this group of patients (Yeo et al. 2003). Importantly, we have been unable to demonstrate evidence for dominant negativity associated with these mutants, which suggests that $M C 4 R$ mutations are more likely to result in a phenotype through haploinsufficiency.

\section{CONCLUSIONS}

Body mass index is a highly heritable human trait. Despite legitimate concerns about the environmental forces responsible for recent secular changes in its prevalence, this fact has not altered. Our knowledge of the molecules involved in the control of human body fat mass has increased dramatically, largely from the study of humans who become severely obese from a young age. Notably, in the vast majority of cases described to date, the causative mutation disrupts the function of hypothalamic integrative centres and results in increased food intake. Progress has been slower in identifying common genetic variants that underlie susceptibility/resistance to obesity in the general population. However, it is highly likely that such variants will affect similar pathways to those revealed by the rare monogenic defects. If that is the case, then it might eventually be necessary to reclassify obesity from a 'metabolic' disorder to a 'neuro-behavioural' one.

\section{REFERENCES}

Allison, D. B., Kaprio, J., Korkeila, M., Koskenvuo, M., Neale, M. C. \& Hayakawa, K. 1996 The heritability of body mass index among an international sample of monozygotic twins reared apart. Int. $\mathcal{F}$. Obes. Relat. Metab. Disord. 20, 501-506.

Amos-Landgraf, J. M. et al. 1999 Chromosome breakage in the Prader-Willi and Angelman syndromes involves recombination between large, transcribed repeats at proximal and distal breakpoints. Am. F. Hum. Genet. 65, 370-386. (doi:10.1086/302510)

Ansley, S. J. et al. 2003 Basal body dysfunction is a likely cause of pleiotropic Bardet-Biedl syndrome. Nature 425, 628-633. (doi:10.1038/nature02030)

Aronne, L. J. 2002 Classification of obesity and assessment of obesity-related health risks. Obes. Res. 10(Suppl. 2), 105S-115S.

Badano, J. L., Ansley, S. J., Leitch, C. C., Lewis, R. A., Lupski, J. R. \& Katsanis, N. 2003 Identification of a novel Bardet-Biedl syndrome protein, BBS7, that shares structural features with BBS1 and BBS2. Am. F. Hum. Genet. 72, 650-658. (doi:10.1086/368204)

Barsh, G. S., Farooqi, I. S. \& O'Rahilly, S. 2000 Genetics of body-weight regulation. Nature 404, 644-651.

Beales, P. L. 2005 Lifting the lid on Pandora's box: the Bardet-Biedl syndrome. Curr. Opin. Genet. Dev. 15, 315-323. (doi:10.1016/j.gde.2005.04.006)

Bouchard, C. \& Tremblay, A. 1990 Genetic effects in human energy expenditure components. Int. f. Obes. 49-55, discussion 55-8.

Bouchard, C. et al. 1990 The response to long-term overfeeding in identical twins. N. Engl. F. Med. 322, 1477-1482.

Bouchard, C., Tremblay, A., Despres, J. P., Nadeau, A., Lupien, P. J., Moorjani, S., Theriault, G. \& Kim, S. Y. 1996 Overfeeding in identical twins: 5-year postoverfeeding results. Metabolism 45, 1042-1050. (doi:10.1016/ S0026-0495(96)90277-2)

Boutin, P. et al. 2003 GAD2 on chromosome $10 \mathrm{p} 12$ is a candidate gene for human obesity. PLoS Biol. 1, E68. (doi:10.1371/journal.pbio.0000068)

Challis, B. G. et al. 2002 A missense mutation disrupting a dibasic prohormone processing site in pro-opiomelanocortin (POMC) increases susceptibility to early-onset obesity through a novel molecular mechanism. Hum. Mol. Genet. 11, 1997-2004. (doi:10.1093/hmg/11.17. 1997)

Chung, W. K., Belfi, K., Chua, M., Wiley, J., Mackintosh, R., Nicolson, M., Boozer, C. N. \& Leibel, R. L. 1998 Heterozygosity for Lep(ob) or Lep(rdb) affects body composition and leptin homeostasis in adult mice. Am. f. Physiol. 274, R985-R990.

Clement, K. et al. 1998 A mutation in the human leptin receptor gene causes obesity and pituitary dysfunction. Nature 392, 398-401. (doi:10.1038/32911)

Coll, A. P., Farooqi, I. S., Challis, B. G., Yeo, G. S. \& O'Rahilly, S. 2004 Proopiomelanocortin and energy balance: insights from human and murine genetics. f. Clin. Endocrinol. Metab. 89, 2557-2562. (doi:10.1210/ jc.2004-0428)

Comuzzie, A. G. 2002 The emerging pattern of the genetic contribution to human obesity. Best Pract. Res. Clin. Endocrinol. Metab. 16, 611-621. (doi:10.1053/beem.2002. 0224)

Comuzzie, A. G., Hixson, J. E., Almasy, L., Mitchell, B. D., Mahaney, M. C., Dyer, T. D., Stern, M. P., MacCluer, J. W. \& Blangero, J. 1997 A major quantitative trait locus determining serum leptin levels and fat mass is located on human chromosome 2. Nat. Genet. 15, 273-276. (doi:10. 1038/ng0397-273)

Comuzzie, A. G., Williams, J. T., Martin, L. J. \& Blangero, J. 2001 Searching for genes underlying normal variation in human adiposity. F. Mol. Med. 79, 57-70. (doi:10.1007/ s001090100202)

Cummings, D. E., Clement, K., Purnell, J. Q., Vaisse, C., Foster, K. E., Frayo, R. S., Schwartz, M. W., Basdevant, A. \& Weigle, D. S. 2002 Elevated plasma ghrelin levels in Prader 
Willi syndrome. Nat. Med. 8, 643-644. (doi:10.1038/ nm0702-643)

Farooqi, I. S., Keogh, J. M., Kamath, S., Jones, S., Gibson, W. T., Trussell, R., Jebb, S. A., Lip, G. Y. \& O'Rahilly, S. 2001 Partial leptin deficiency and human adiposity. Nature 414, 34-35. (doi:10.1038/35102112)

Farooqi, I. S. et al. 2002 Beneficial effects of leptin on obesity, $\mathrm{T}$ cell hyporesponsiveness, and neuroendocrine/metabolic dysfunction of human congenital leptin deficiency. F. Clin. Invest. 110, 1093-1103. (doi:10.1172/JCI200215693)

Farooqi, I. S., Keogh, J. M., Yeo, G. S., Lank, E. J., Cheetham, T. \& O'Rahilly, S. 2003 Clinical spectrum of obesity and mutations in the melanocortin 4 receptor gene. N. Engl. F. Med. 348, 1085-1095. (doi:10.1056/ NEJMoa022050)

Gantz, I. \& Fong, T. M. 2003 The melanocortin system. Am. 7. Physiol. Endocrinol. Metab. 284, E468-E474.

Geller, F. et al. 2004 Melanocortin-4 receptor gene variant I103 is negatively associated with obesity. Am. F. Hum. Genet. 74, 572-581. (doi:10.1086/382490)

Goodpaster, B. H. 2002 Measuring body fat distribution and content in humans. Curr. Opin. Clin. Nutr. Metab. Care 5, 481-487. (doi:10.1097/00075197-200209000-00005)

Hager, J. et al. 1998 A genome-wide scan for human obesity genes reveals a major susceptibility locus on chromosome 10. Nat. Genet. 20, 304-308. (doi:10.1038/3123)

Halaas, J. L., Gajiwala, K. S., Maffei, M., Cohen, S. L., Chait, B. T., Rabinowitz, D., Lallone, R. L., Burley, S. K. \& Friedman, J. M. 1995 Weight-reducing effects of the plasma protein encoded by the obese gene. Science 269, 543-546.

Hanson, R. L. et al. 1998 An autosomal genomic scan for loci linked to type II diabetes mellitus and body-mass index in Pima Indians. Am. F. Hum. Genet. 63, 1130-1138. (doi:10.1086/302061)

Haqq, A. M., Farooqi, I. S., O'Rahilly, S., Stadler, D. D., Rosenfeld, R. G., Pratt, K. L., LaFranchi, S. H. \& Purnell, J. Q. 2003 Serum ghrelin levels are inversely correlated with body mass index, age, and insulin concentrations in normal children and are markedly increased in PraderWilli syndrome. F. Clin. Endocrinol. Metab. 88, 174-178. (doi:10.1210/jc.2002-021052)

Hixson, J. E. et al. 1999 Normal variation in leptin levels in associated with polymorphisms in the proopiomelanocortin gene, POMC. Clin. Endocrinol. Metab. 84, 3187-3191. (doi:10.1210/jc.84.9.3187)

Huang, E. J. \& Reichardt, L. F. 2001 Neurotrophins: roles in neuronal development and function. Annu. Rev. Neurosci. 24, 677-736. (doi:10.1146/annurev.neuro.24.1.677)

Huszar, D. et al. 1997 Targeted disruption of the melanocortin-4 receptor results in obesity in mice. Cell 88, 131-141. (doi:10.1016/S0092-8674(00)81865-6)

Jackson, R. S., Creemers, J. W., Ohagi, S., Raffin-Sanson, M. L., Sanders, L., Montague, C. T., Hutton, J. C. \& O'Rahilly, S. 1997 Obesity and impaired prohormone processing associated with mutations in the human prohormone convertase 1 gene. Nat. Genet. 16, 303-306. (doi:10.1038/ng0797-303)

Jackson, R. S. et al. 2003 Small-intestinal dysfunction accompanies the complex endocrinopathy of human proprotein convertase 1 deficiency. F. Clin. Invest. 112, 1550-1560. (doi:10.1172/JCI200318784)

Jebb, S. A., Rennie, K. L. \& Cole, T. J. 2004 Prevalence of overweight and obesity among young people in Great Britain. Public Health Nutr. 7, 461-465. (doi:10.1079/ PHN2003539)

Katsanis, N. et al. 2001a Triallelic inheritance in BardetBiedl syndrome, a Mendelian recessive disorder. Science 293, 2256-2259. (doi:10.1126/science.1063525)
Katsanis, N., Lupski, J. R. \& Beales, P. L. $2001 b$ Exploring the molecular basis of Bardet-Biedl syndrome. Hum. Mol. Genet. 10, 2293-2299. (doi:10.1093/hmg/10.20.2293)

Kernie, S. G., Liebl, D. J. \& Parada, L. F. 2000 BDNF regulates eating behavior and locomotor activity in mice. Embo. F. 19, 1290-1300. (doi:10.1093/emboj/19.6.1290)

Kissebah, A. H. et al. 2000 Quantitative trait loci on chromosomes 3 and 17 influence phenotypes of the metabolic syndrome. Proc. Natl Acad. Sci. USA 97, 14 478-14 483. (doi:10.1073/pnas.97.26.14478)

Kopelman, P. G. 2000 Obesity as a medical problem. Nature 404, 635-643.

Krude, H., Biebermann, H., Luck, W., Horn, R., Brabant, G. \& Gruters, A. 1998 Severe early-onset obesity, adrenal insufficiency and red hair pigmentation caused by POMC mutations in humans. Nat. Genet. 19, 155-157. (doi:10. 1038/509)

Larsen, L. H., Echwald, S. M., Sorensen, T. I., Andersen, T., Wulff, B. S. \& Pedersen, O. 2005 Prevalence of mutations and functional analyses of melanocortin 4 receptor variants identified among 750 men with juvenile-onset obesity. F. Clin. Endocrinol. Metab. 90, 219-224. (doi:10. 1210/jc.2004-0497)

Le Stunff, C., Fallin, D. \& Bougneres, P. 2001 Paternal transmission of the very common class I INS VNTR alleles predisposes to childhood obesity. Nat. Genet. 29, 96-99. (doi:10.1038/ng707)

Lee, S., Walker, C. L., Karten, B., Kuny, S. L., Tennese, A. A., O'Neill, M. A. \& Wevrick, R. 2005 Essential role for the Prader-Willi syndrome protein necdin in axonal outgrowth. Hum. Mol. Genet. 14, 627-637. (doi:10. 1093/hmg/ddi059)

Leibel, R. L., Chung, W. K. \& Chua Jr, S. C. 1997 The molecular genetics of rodent single gene obesities. F. Biol. Chem. 272, 31 937-31 940. (doi:10.1074/jbc.272.51. 31937)

Lindi, V. I. et al. 2002 Association of the Pro12Ala polymorphism in the PPAR-gamma2 gene with 3-year incidence of type 2 diabetes and body weight change in the finnish diabetes prevention study. Diabetes 51, 2581-2586.

Maes, H. H., Neale, M. C. \& Eaves, L. J. 1997 Genetic and environmental factors in relative body weight and human adiposity. Behav. Genet. 27, 325-351. (doi:10.1023/ A:1025635913927)

Meirhaeghe, A., Helbecque, N., Cottel, D., Auwerx, J., Deeb, S. S. \& Amouyel, P. $2000 a$ Impact of the peroxisome proliferator activated receptor gamma2 Pro12Ala polymorphism on adiposity, lipids and noninsulin-dependent diabetes mellitus. Int. F. Obes. Relat. Metab. Disord. 24, 195-199. (doi:10.1038/sj.ijo.0801112)

Meirhaeghe, A., Cottel, D. \& Amouyel, P. $2000 \mathrm{~b}$ Impact of polymorphisms of the human beta2-adrenoceptor gene on obesity in a French population. Int. F. Obes. Relat. Metab. Disord. 24, 382-387. (doi:10.1038/sj.ijo.0801168)

Meirhaeghe, A., Luan, J., Selberg-Franks, P., Hennings, S., Mitchell, J., Halsall, D., O'Rahilly, S. \& Wareham, N. J. 2001 The effect of the Gly16Arg polymorphism of the beta(2)-adrenergic receptor gene on plasma free fatty acid levels is modulated by physical activity. F. Clin. Endocrinol. Metab. 86, 5881-5887. (doi:10.1210/jc.86.12.5881)

Montague, C. T. et al. 1997 Congenital leptin deficiency is associated with severe early-onset obesity in humans. Nature 387, 903-908. (doi:10.1038/43185)

Mykytyn, K. \& Sheffield, V. C. 2004 Establishing a connection between cilia and Bardet-Biedl Syndrome. Trends Mol. Med. 10, 106-109. (doi:10.1016/j.molmed. 2004.01.003)

Mykytyn, K. et al. 2001 Identification of the gene that, when mutated, causes the human obesity syndrome BBS4. Nat. Genet. 28, 188-191. (doi:10.1038/88925) 
Mykytyn, K. et al. 2002 Identification of the gene (BBS1) most commonly involved in Bardet-Biedl syndrome, a complex human obesity syndrome. Nat. Genet. 31, 435-438.

Mykytyn, K. et al. 2004 Bardet-Biedl syndrome type 4 (BBS4)-null mice implicate Bbs4 in flagella formation but not global cilia assembly. Proc. Natl Acad. Sci. USA 101, 8664-8669. (doi:10.1073/pnas.0402354101)

Nishimura, D. Y. et al. 2001 Positional cloning of a novel gene on chromosome 16q causing Bardet-Biedl syndrome (BBS2). Hum. Mol. Genet. 10, 865-874. (doi:10.1093/ $\mathrm{hmg} / 10.8 .865)$

Nishimura, D. Y. et al. 2004 Bbs2-null mice have neurosensory deficits, a defect in social dominance, and retinopathy associated with mislocalization of rhodopsin. Proc. Natl Acad. Sci. USA 101, 16 588-16 593. (doi:10.1073/pnas. 0405496101)

Norman, R. A. et al. 1998 Autosomal genomic scan for loci linked to obesity and energy metabolism in Pima Indians. Am. F. Hum. Genet. 62, 659-668. (doi:10.1086/ 301758)

Ohman, M., Oksanen, L., Kaprio, J., Koskenvuo, M., Mustajoki, P., Rissanen, A., Salmi, J., Kontula, K. \& Peltonen, L. 2000 Genome-wide scan of obesity in Finnish sibpairs reveals linkage to chromosome Xq24. 7. Clin. Endocrinol. Metab. 85, 3183-3190. (doi:10.1210/ jc.85.9.3183)

O'Rahilly, S., Gray, H., Humphreys, P. J., Krook, A., Polonsky, K. S., White, A., Gibson, S., Taylor, K. \& Carr, C. 1995 Brief report: impaired processing of prohormones associated with abnormalities of glucose homeostasis and adrenal function. N. Engl. F. Med. 333, 1386-1390. (doi:10.1056/NEJM199511233332104)

Ozata, M., Ozdemir, I. C. \& Licinio, J. 1999 Human leptin deficiency caused by a missense mutation: multiple endocrine defects, decreased sympathetic tone, and immune system dysfunction indicate new targets for leptin action, greater central than peripheral resistance to the effects of leptin, and spontaneous correction of leptinmediated defects. F. Clin. Endocrinol. Metab. 84, 3686-3695. (doi:10.1210/jc.84.10.3686)

Price, R. A. \& Gottesman, I. I. 1991 Body fat in identical twins reared apart: roles for genes and environment. Behav. Genet. 21, 1-7. (doi:10.1007/BF01067662)

Rios, M., Fan, G., Fekete, C., Kelly, J., Bates, B., Kuehn, R., Lechan, R. M. \& Jaenisch, R. 2001 Conditional deletion of brain-derived neurotrophic factor in the postnatal brain leads to obesity and hyperactivity. Mol. Endocrinol. 15, 1748-1757. (doi:10.1210/me.15.10.1748)

Samaras, K., Kelly, P. J., Chiano, M. N., Spector, T. D. \& Campbell, L. V. 1999 Genetic and environmental influences on total-body and central abdominal fat: the effect of physical activity in female twins. Ann. Intern. Med. 130, 873-882.

Schwartz, M. W., Woods, S. C., Porte Jr, D., Seeley, R. J. \& Baskin, D. G. 2000 Central nervous system control of food intake. Nature 404, 661-671.

Sheffield, V. C., Carmi, R., Kwitek-Black, A., Rokhlina, T., Nishimura, D., Duyk, G. M., Elbedour, K., Sunden, S. L. \& Stone, E. M. 1994 Identification of a Bardet-Biedl syndrome locus on chromosome 3 and evaluation of an efficient approach to homozygosity mapping. Hum. Mol. Genet. 3, 1331-1335.
Slavotinek, A. M. et al. 2000 Mutations in MKKS cause Bardet-Biedl syndrome. Nat. Genet. 26, 15-16. (doi:10. 1038/79116)

Sorensen, T. I., Price, R. A., Stunkard, A. J. \& Schulsinger, F. 1989 Genetics of obesity in adult adoptees and their biological siblings. Br. Med. f. 298, 87-90.

Strobel, A., Issad, T., Camoin, L., Ozata, M. \& Strosberg, A. D. 1998 A leptin missense mutation associated with hypogonadism and morbid obesity. Nat. Genet. 18, 213-215. (doi:10.1038/ng0398-213)

Stunkard, A. J., Foch, T. T. \& Hrubec, Z. $1986 a$ A twin study of human obesity. F. Am. Med. Assoc. 256, 51-54. (doi:10. 1001/jama.256.1.51)

Stunkard, A. J., Sorensen, T. I., Hanis, C., Teasdale, T. W., Chakraborty, R., Schull, W. J. \& Schulsinger, F. 1986b An adoption study of human obesity. N. Engl. F. Med. 314, 193-198.

Stunkard, A. J., Harris, J. R., Pedersen, N. L. \& McClearn, G. E. 1990 The body-mass index of twins who have been reared apart. N. Engl. F. Med. 322, 1483-1487.

Suviolahti, E. et al. 2003 The SLC6A14 gene shows evidence of association with obesity. $\mathcal{F}$. Clin. Invest. 112, 1762-1772. (doi:10.1172/JCI200317491)

Swaab, D. F., Purba, J. S. \& Hofman, M. A. 1995 Alterations in the hypothalamic paraventricular nucleus and its oxytocin neurons (putative satiety cells) in Prader-Willi syndrome: a study of five cases. F. Clin. Endocrinol. Metab. 80, 573-579. (doi:10.1210/jc.80.2.573)

t Hart, L. M. et al. 2004 Genetic factors and insulin secretion: gene variants in the IGF genes. Diabetes 53(Suppl. 1), S26-S30.

Tartaglia, L. A. 1997 The leptin receptor. F. Biol. Chem. 272, 6093-6096.

Ulijaszek, S. 2005 Modernisation, migration and nutritional health of Pacific Island populations. Environ. Sci. 12, 167-176.

Wade, J., Milner, J. \& Krondl, M. 1981 Evidence for a physiological regulation of food selection and nutrient intake in twins. Am. F. Clin. Nutr. 34, 143-147.

Xu, B., Goulding, E. H., Zang, K., Cepoi, D., Cone, R. D., Jones, K. R., Tecott, L. H. \& Reichardt, L. F. 2003 Brainderived neurotrophic factor regulates energy balance downstream of melanocortin-4 receptor. Nat. Neurosci. 6, 736-742. (doi:10.1038/nn1073)

Yeo, G. S., Lank, E. J., Farooqi, I. S., Keogh, J., Challis, B. G. \& O'Rahilly, S. 2003 Mutations in the human melanocortin-4 receptor gene associated with severe familial obesity disrupts receptor function through multiple molecular mechanisms. Hum. Mol. Genet. 12, 561-574. (doi: 10.1093/hmg/ddg057)

Yeo, G. S., Connie Hung, C. C., Rochford, J., Keogh, J., Gray, J., Sivaramakrishnan, S., O'Rahilly, S. \& Farooqi, I. S. $2004 \mathrm{~A}$ de novo mutation affecting human TrkB associated with severe obesity and developmental delay. Nat. Neurosci. 7, 1187-1189. (doi:10.1038/nn1336)

Young, T. L., Penney, L., Woods, M. O., Parfrey, P. S., Green, J. S., Hefferton, D. \& Davidson, W. S. 1999 A fifth locus for Bardet-Biedl syndrome maps to chromosome 2q31. Am. f. Hum. Genet. 64, 900-904. (doi:10.1086/302301)

Zhang, Y., Proenca, R., Maffei, M., Barone, M., Leopold, L. \& Friedman, J. M. 1994 Positional cloning of the mouse obese gene and its human homologue. Nature 372, 425-432. (doi:10.1038/372425a0) 